УДК 55(092)

\title{
К юбилею академика РАЕ Фаины Алексеевны Курбацкой
}

\section{Н.Е. Молоштанова, Н.А. Бусыгина}

Пермский государственный национальный исследовательский университет, 614990, Пермь, ул. Букирева, 15. E-mail: mineral@psu.ru

(Статья поступила в редакичию 29 мая 2017 г.)

Приведены краткие сведения о производственной, учебной, научной и организаторской деятельности доктора геолого-минералогических наук, академика РАE, профессора и заведующей кафедрой минералогии и петрографии ПГНИУ Фаины Алексеевны Курбацкой

DOI: 10.17072/psu.geol.16.2.197

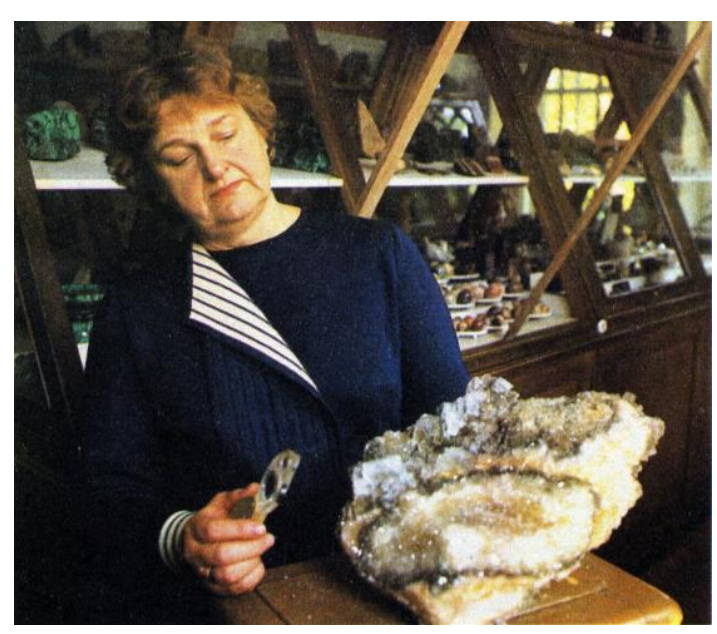

В 1950 г. Ф.А. Курбацкая поступила в Пермский университет, где обучалась у проф. П.Н. Чирвинского. После его окончания 9 лет проработала в Пермской геологоразведочной экспедиции. С 1965 г. она училась в аспирантуре при кафедре минералогии и петрографии Пермского госуниверситета под руководством доцента Н.А. Игнатьева и в 1968 г. защитила кандидатскую диссертацию «Корреляция терригенных толщ верхнего докембрия западного склона Среднего Урала и условия их образования». В 1967 г. она была зачислена на должность старшего преподавателя кафедры, в 1971 - доцента, в 1976-1978 гг. - старшего научного сотрудника для подготовки докторской диссертации. С 1979 по 1997 г. она возглавляла кафедру. В 1985 г. Ф.А. Курбацкая защитила в МГУ докторскую диссертацию «Формации и палеотектоника Ураль- ской окраины Восточно-Европейской платформы в позднем докембрии». В 1997 г. она стала академиком Российской академии естествознания (РАЕ).

Главные научные интересы Ф.А. Курбацкой связаны с геологией позднего докембрия Западного Урала. Это касается разработки стратиграфии рифея и венда, литологического изучения пород, характера их вторичных изменений, выделения осадочных формаций, прогноза полезных ископаемых. Она доказала существование рифтогенного этапа в истории развития региона.

За время работы на кафедре минералогии и петрографии ею опубликовано более 130 работ, из них 5 монографий, 3 учебных пособия, которыми студенты пользуются до настоящего времени: «Петрография кристаллических пород с основами кристаллооптики», «Методы исследования осадочных пород» (лабораторный практикум) и «Атлас терригенных и эксплозивно-инъекционных пород западного склона Северного и Среднего Урала». Участвовала в написании 25 геологических отчетов.

Наряду с научными исследованиями Фаина Алексеевна занималась большой общественной работой. Будучи депутатом Дзержинского райсовета, она способствовала улучшению жилищных условий сотрудников нашей кафедры. Ветеран Отечественной войны Н.И. Громыхалова и ветеран кафедры А.М. Кропачев получили 
новые квартиры. Ф.А. Курбацкая принимала активное участие в решении вопроса о строительстве нового корпуса геологического факультета.

Лекции Фаины Алексеевны всегда были интересными, глубокими, с большим количеством примеров. Студентам они нравились. Их посещали и начинающие, молодые преподаватели. Она была доброжелательна к коллегам, помогала в затруднительных ситуациях.За время своей работы в университете Ф.А. Курбацкая дала «путёвку в жизнь» многим ученикам, которые работают на благо нашей страны.

Ей присвоены звания «Заслуженный работник высшей школы Российской Федерации» «Заслуженный деятель науки и техники». В честь юбилея РАЕ (19952015) она награждена орденом Александра Великого «За научные победы и свершения».

Фаина Алексеевна отмечает юбилей 27 июня 2017 г. От всего сердца коллектив кафедры поздравляет её с замечательной датой! Желаем крепкого здоровья и бодрости!

\section{Библиографический список}

Аблизин Б.Д., Клюжина М.Л., Курбаикая Ф.А., Курбаикий А.М. Верхний рифей и венд западного склона Среднего Урала. М.: Наука, 1982. $140 \mathrm{c}$.

Курбацккая Ф.А. Корреляция терригенных толщ верхнего докембрия западного склона Среднего Урала и условия их образования: автореф. дис. ... канд. геол.-минер. наук. Пермь, 1968. 25 с.

Курбацкая Ф.А. Формации и палеотектоника Уральской окраины ВосточноЕвропейской платформы в позднем докембрии: автореф. дис. ... докт. геол.-минер. наук. М.: Изд-во МГУ, 1985. 38 с.

Курбачкая Ф.А., Рыбальченко Т.М., Савченко C.B. Атлас микрофотографий терригенных и эксплозивно-инъекционных пород западного склона Северного и Среднего Урала. Пермь, 2001. 124 с.

\title{
To Jubilee of Academician Faina Alekseevna Kurbatskaya
}

\author{
N.E. Moloshtanova, N.A. Busygina \\ Perm State University, 15 Bukireva Str., Perm, 614990, Russia \\ E-mail: mineral@psu.ru
}

The brief review of geological, teaching, scientific, and organizing activity of Doctor of Geological-Mineralogical Sciences, Academician of the Academy of Natural Sciences of Russia, professor of Mineralogy and Petrography Department of the Perm State University Faina Alekseevna Kurbatskaya is presented. 